\begin{tabular}{|l|l|l|}
\hline \multicolumn{2}{|c|}{ PublisherInfo } \\
\hline \hline PublisherName & $:$ & BioMed Central \\
\hline \hline PublisherLocation & $:$ & London \\
\hline \hline PublisherImprintName & $:$ & BioMed Central \\
\hline \hline
\end{tabular}

\title{
Quantitative gene expression
}

\begin{tabular}{|l|l|l||}
\hline \multicolumn{2}{|c||}{ ArticleInfo } \\
\hline \hline ArticleID & $:$ & 4727 \\
\hline \hline ArticleDOI & $:$ & 10.1186 /gb-spotlight-20030320-01 \\
\hline \hline ArticleCitationID & $:$ & spotlight-20030320-01 \\
\hline \hline ArticleSequenceNumber & $:$ & 79 \\
\hline \hline ArticleCategory & $:$ & Research news \\
\hline ArticleFirstPage & $:$ & 1 \\
\hline \hline ArticleLastPage & $:$ & 2 \\
\hline \hline & & RegistrationDate : 2003-3-20 \\
\hline ArticleHistory & $:$ & OnlineDate \\
\hline \hline ArticleCopyright & $:$ & BioMed Central Ltd2003-20 \\
\hline \hline ArticleGrants & $:$ & \\
\hline \hline ArticleContext & $:$ & 130594411 \\
\hline \hline
\end{tabular}




\section{Richard Robinson}

Email: rrobinson@nasw.org

Gene expression profiling provides information on differential expression for thousands of genes at once. These differences may themselves be under genetic control, and sequence variations at some loci may exert local or regional influences affecting these same levels of expression. In the March 20 Nature, Eric Schadt and colleagues at the Merck Research Laboratories, West Point, Pennsylvania, US, demonstrate the existence of such loci in mouse, human, and maize, and identify a differential gene expression pattern in mice strongly associated with obesity (Nature, 422:297-302, March 20, 2003).

Friend et al. profiled expression of more than 23,000 genes in the third-generation offspring (F2) of two inbred strains of mice. Of these, more than 7000 showed a significant difference in expression level between the strains. They also sequenced 100 microsatellite markers evenly spaced across the murine chromosomes. Treating variations in expression levels as quantitative traits, and using standard genetic analysis tools, they identified several thousand "expression quantitative trait loci" which explained more than $25 \%$ of the observed differences in gene expression. Many of these affected expression of their genetic neighbors most strongly, a pattern also seen in analysis of maize. A preliminary study in humans showed that approximately $30 \%$ of more than 2500 differentially expressed genes had a detectable genetic component to their expression level. In mice subgrouped on the basis of fat pad mass, they identified five eQTLs associated with differences in obesity, indicating the potential of this technique for identifying gene expression patterns associated with disease states or predispositions.

"Unlike classical quantitative traits, which often represent gross clinical measurements that may be far removed from the biological processes giving rise to them, the genetic linkages associated with transcript abundance affords a closer look at biochemical processes," conclude the authors.

In an accompanying News and Views article, Ariel Darvasi of the Hebrew University, Jerusalem, Israel, notes that this technique can be applied to any organism for which both genome expression profiling and genome-wide genetic analysis can be performed efficiently.

\section{References}

1. Genetic dissection of transcriptional regulation in budding yeast.,

2. Nature, [http://www.nature.com/]

3. Merck Research Laboratories, [http://www.merck.com/mrc/]

4. Hebrew University, Jerusalem, [http://www.huji.ac.il] 